\title{
Hadley v. Baxendale and Other Common Law Borrowings from the Civil Law
}

Wayne Barnes

Texas A\&M University School of Law, wbarnes@law.tamu.edu

Follow this and additional works at: https://scholarship.law.tamu.edu/facscholar

Part of the Common Law Commons, and the Legal History Commons

\section{Recommended Citation}

Wayne Barnes, Hadley v. Baxendale and Other Common Law Borrowings from the Civil Law, 11 Tex. Wesleyan L. Rev. 627 (2005).

Available at: https://scholarship.law.tamu.edu/facscholar/287

This Article is brought to you for free and open access by Texas A\&M Law Scholarship. It has been accepted for inclusion in Faculty Scholarship by an authorized administrator of Texas A\&M Law Scholarship. For more information, please contact aretteen@law.tamu.edu. 


\section{HADLEY V. BAXENDALE AND OTHER COMMON LAW BORROWINGS FROM THE CIVIL LAW}

Wayne Barnes $\dagger$

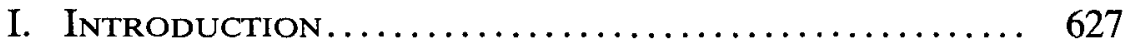

II. Hadley V. BaXendale-A "Judicial INVENTION"?............................... 629

A. The Facts and the Holding of the Case .......... 629

B. The True Civilian Heritage of the Hadley Rule..... 631

C. Blanchard v. Ely: Predecessor to Hadley Which Overtly Acknowledged the Civil Law ............ 634

D. The Lineage of the Rule Limiting Contracts Damages on the Basis of Foreseeability ........... 636

III. The Concept of Legal Borrowing Generally .... 638

A. The History of Common Law Borrowing from the

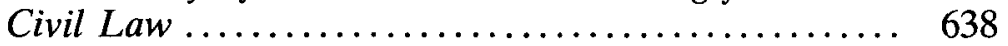

B. The Debate About the Correlation Between Societies and the Development of the Rule of Law ......... 639

IV. EXAMPLes OF OTHER COMMON LAW Borrowing FROM THE Civil LAW ........................... 642

A. The Privilege Against Self-Incrimination .......... 643

B. Mitior Sensus Doctrine in Law of Defamation ...... 644

C. Law of Conflicts ............................ 645

D. Mistake Doctrine in Contracts Cases ............. 646

E. Rules of Equity ........................... 646

F. Rules of Civil Procedure ....................... 647

V. Conclusion ............................... 648

\section{INTRODUCTION}

In 1854, the English Exchequer Court delivered the landmark case of Hadley v. Baxendale. ${ }^{1}$ That case provided, for the first time in the common law, a defined rule regarding the limitations on recovery of damages for breach of contract. It has been widely celebrated as a landmark in the law of contracts, and more widely as a triumph of the common law system. A little over a decade after it was decided, it had already become highly regarded, for Chief Baron Pollock stated in

$\dagger$ Associate Professor, Texas Wesleyan University School of Law. Some of the ideas in this Article were originally presented at the conference celebrating the 150th Anniversary of Hadley v. Baxendale: "The Common Law of Contracts as a World Force in Two Ages of Revolution," which was held on June 7-8, 2004, in Gloucester, England, at the University of Gloucestershire, Oxtalls Campus. I benefited from discussions I had with many of the conference participants, including Joseph M. Perillo, Andrew Tettenborn, Dr. Florian Faust, Frank Snyder, and Joe Spurlock.

1. 156 Eng. Rep. 145 (Ex. 1854). 
1866: "'A] more extensive and accurate knowledge of decisions in our law books, and a more accurate power of analyzing and discussing them, and ... a larger acquaintance with the exigencies of commerce and the business of life, never combined to assist at the formation of any decision." "2 White and Summers state that knowledge of the case " "has become a sine qua non to second-year standing in law school." 3 Richard Danzig notes the "pedagogical centrality" of the case and its characterization as a "judicial invention." 4 Corbin has claimed that Hadley is "more often cited as authority than any other case in the law of damages." "5 A German scholar, Florian Faust, notes that Hadley's "fame is based on the fact that the case formally introduced the rule of foreseeability into the common law of contract ...." Perhaps most famously of all, Grant Gilmore stated that "Hadley v. Baxendale is still, and presumably always will be, a fixed star in the jurisprudential firmament."

Is this recognition deserved? To some extent, inarguably it is. But is the judicial "inventiveness" ascribed to the Hadley court fully warranted? Was it created out of whole-cloth by ingenious practitioners of the common law? This Article seeks to answer that question, though the title perhaps eliminates any attempt at suspense, for the civil law was most assuredly referenced for the Hadley rule. After this initial introduction, Part II of this Article will discuss the facts and holding of the Hadley case, and describe fully the civilian sources for the rules announced by the Hadley court. Part III will discuss generally the concept of legal transplants, and the interrelation between the development of a particular legal rule and the context of the society in which it is promulgated. Part IV will present, by way of illustration and example only, a handful of other instances in which Anglo-American courts have borrowed from the civil law for purposes of "creating" new common law doctrine. Part $\mathrm{V}$ will offer some concluding remarks.

2. Florian Faust, Hadley v. Baxendale-An Understandable Miscarriage of Justice, 15 J. Legal Hist. 41, 41-42 (1994) (quoting Wilson v. Newport Dock Co., 35 L.J.R. (N.S.) Ex. 97, 103 (1866)).

3. Richard Danzig, Hadley v. Baxendale: A Study in the Industrialization of the Law, 4 J. Legal Stud. 249, 249 n.2 (1975) (quoting J. White \& R. Summers, Handbook of The Law Under the Uniform Commercial Code 314 (1972)).

4. Id. at 249-50, 254.

5. Faust, supra note 2, at 41 (quoting S.A.L. Corbin, Corbin on Contracts 5, 93 (1951)).

6. Id.

7. Grant Gilmore, The Death of Contract 92 (Ronald K. L. Collins ed., 2d ed. 1995). Interestingly, Gilmore also stated about Hadley: "[W]hy such an essentially uninteresting case, decided in a not very good opinion by a judge otherwise unknown to fame, should immediately have become celebrated on both sides of the Atlantic is one of the mysteries of legal history." Id. at 54. 


\section{HadLEY V. BAXENDALE-A "Judicial InVention"?}

\section{A. The Facts and the Holding of the Case}

The plaintiffs in the case, the Hadleys, owned and operated a flour mill in Gloucester, England. ${ }^{8}$ On May 11, 1853, the crankshaft of the mill broke, which stopped the mill. ${ }^{9}$ The Hadleys discovered the broken shaft on May 12th, and the next day they sent one of their employees to Pickfords, a local carrier owned by Baxendale, to inquire as to the logistics for having the shaft delivered to W. Joyce and Co., the original manufacturer, for purposes of having a new shaft made for the mill. ${ }^{10}$ When the Hadleys' employee asked about the expected turnaround for the delivery, he was told that if the shaft were to be received by noon on any particular day, it could be expected to reach W. Joyce and Co., located in Greenwich, by the next day thereafter. ${ }^{11}$ The shaft was eventually delivered to Pickfords for carriage-however, rather than being delivered the next day, through neglect it was delayed for several days before being eventually delivered. ${ }^{12}$ The Hadley's mill, being shut down during this entire period, thereby suffered lost profits occasioned by the delay, for which they sued. ${ }^{13}$

The Hadleys claimed lost profits of $£ 300 .{ }^{14}$ Baxendale was willing to pay only $£ 25$, and thus the Hadleys pressed for a full trial. ${ }^{15}$ At the original trial, heard by a jury of peers and presided over by Judge Crompton, the jury was instructed as follows:

[You must] . . consider what, under the circumstance was a reasonable time for delivering the shaft; and next, what was the damages caused to the Plaintiffs by the delay in the delivery. ... They should give their damages for the natural consequences of the defendant's breach of contract, ... . and then, looking to all the circumstances of the case and the position of the parties, to say what was the amount of the damages occasioned by the stoppage of the works. ${ }^{16}$

After the jury returned a verdict of $£ 50$, Baxendale appealed. After hearing arguments from both parties, the Exchequer Court announced the following rule:

Now we think the proper rule in such a case as the present is this: Where two parties have made a contract which one of them has broken, the damages which the other party ought to receive in respect of such breach of contract should be such as may fairly and

\footnotetext{
8. Hadley v. Baxendale, 156 Eng. Rep. 145, 147 (Ex. 1854).

9. Id.

10. $I d$.

11. $I d$.

12. $I d$.

13. $I d$.

14. $I d$. at 146 .

15. Id. at $146-47$.

16. Danzig, supra note 3, at 252 (quoting Gloucester Journal, SupPlement August 13, 1853, at 1, col. 4).
} 
reasonably be considered either arising naturally, i.e., according to the usual course of things, from such breach of contract itself, or such as may reasonably be supposed to have been in the contemplation of both parties, at the time they made the contract, as the probable result of the breach of it. Now, if the special circumstances under which the contract was actually made were communicated by the plaintiffs to the defendants, and thus known to both parties, the damages resulting from the breach of such a contract, which they would reasonably contemplate, would be the amount of injury which would ordinarily follow from a breach of contract under these special circumstances so known and communicated. But, on the other hand, if these special circumstances were wholly unknown to the party breaking the contract, he, at the most, could only be supposed to have had in his contemplation the amount of injury which would arise generally, and in the great multitude of cases not affected by any special circumstances, from such a breach of contract. For, had the special circumstances been known, the parties might have specially provided for the breach of contract by special terms as to the damages in that case; and of this advantage it would be very unjust to deprive them. ${ }^{17}$

Based on this announced new rule, the court went on to determine that it was not foreseeable to Baxendale's company that the Hadleys' mill would be stopped during the delay, and therefore Baxendale could not be held responsible for the lost profits incurred during that time. ${ }^{18}$

In the primary opinion of the case, there is cited no prior case as authority for this proposition. No other statutes, or treatises, or commentaries, are mentioned. ${ }^{19}$ When the opinion is thus read in this isolated sense, for the first time, it would appear to be a view to the phenomenon of common law being created, seemingly out of wholecloth. Thus is it presented to generation upon generation of law students and lawyers alike. Hadley has come to have legendary, celebrated status. ${ }^{20}$ The reasons for this would appear to be those just alluded to-this, after all, is the great common law at work: down in the trenches, ingeniously coming up with practical and experientiallyderived rules to govern the affairs of society. ${ }^{21}$

Nor are English and American scholars alone in celebrating Hadley as the innovative invention of a new rule. In commenting on Article 74 of the Vienna Convention on the International Sale of Goods (CISG), which provides a foreseeability rule for the recovery of dam-

17. Hadley, 156 Eng. Rep. at 151.

18. Id.

19. See Danzig, supra note 3, at 254 .

20. See supra notes $2-7$ and accompanying text.

21. See, e.g., Danzig, supra note 3, at 254-55 ("The opinion broke new ground by establishing a rule for decision by judges in an area of law-the calculation of damages in contracts suits-which had previously been left to almost entirely unstructured decision by English juries."). 
ages much like the rule stated in Hadley, ${ }^{22}$ at least two German scholars have asserted that the CISG rule derives from the Hadley common law rule. ${ }^{23}$ It has similarly been concluded by American scholars that CISG Article 74 is based directly on the Hadley rule. ${ }^{24}$ Thus, it is seen that English, American, and even German scholars, to name a few, view Hadley as a "common law original"- they persist in the belief that Hadley gave the foreseeable damages rule to the world. The reason for the American and British perception would appear obviousa rather proud regard for the great common law decision emanating from their ranks.

\section{B. The True Civilian Heritage of the Hadley Rule}

These self-laudatory praises by common law scholars are surely seen with some bemusement by our civil law brethren. For, quite plainly, and notwithstanding the legendary prowess now attributed to the court, the English Exchequer Court appears to have largely adopted the French civil law in this matter. Though not mentioned in the primary appellate opinion, this can be deduced by comparing the announced rule to a remark made by Baron Parke during the argument of the case: "The sensible rule appears to be that which has been laid down in France, and which is declared in their code-Code Civil, liv. iii. tit. iii. ss. $1149,1150,1151 \ldots$. . 25 The French code sections referred to by Baron Parke provide, respectively, as follows:

Art. 1149: Les dommages et intérêts dus au créancier sont, en général, de la perte qu'il a faite et du gain dont il a été privé, sauf les exceptions et modifications ci-après. (Damages due to a creditor are, as a rule, for the loss which he has suffered and the profit which he has been deprived of, subject to the exceptions and modifications below.)

Art. 1150: Le débiteur n'est tenu que des dommages et intérêts qui ont été prévus ou qu'on a pu prévoir lors du contrat, lorsque ce n'est point par son dol que l'obligation n'est point exécutée. (A debtor is

22. Article 74 of the CISG provides as follows:

Damages for breach of contract by one party consist of a sum equal to the loss, including loss of profit, suffered by the other party as a consequence of the breach. Such damages may not exceed the loss which the party in breach foresaw or ought to have foreseen at the time of the conclusion of the contract, in the light of the facts and matters of which he then knew or ought to have known, as a possible consequence of the breach of contract.

United Nations Convention on Contracts for the International Sale of Goods, opened for signature Apr. 11, 1980, art. 74, S. TREATY Doc. No. 98-9 (1983), 19 I.L.M. 671.

23. Franco Ferrari, Comparative Ruminations on the Foreseeability of Damages in Contract Law, 53 LA. L. Rev. 1257, 1262 (1993) (citing Rolf Herber \& Beate Czerwenka, Internationales KaUfrecht 333 (1991) and Gert ReinHaRt, UNKAUFRECHT 170 (1991)).

24. See generally Arthur G. Murphey, Jr., Consequential Damages in Contracts for the International Sale of Goods and the Legacy of Hadley, 23 GEO. WASH. J. INT'L L. \& ECON. 415 (1989).

25. Hadley v. Baxendale, 156 Eng. Rep. 145, 147 (Ex. 1854). 
liable only for damages which were foreseen or which could have been foreseen at the time of the contract, where it is not through his own intentional breach that the obligation is not fulfilled.)

Art. 1151: Dans le cas même où l'inexécution de la convention résulte du dol du débiteur, les dommages et intérêts ne doivent comprendre à l'égard de la perte éprouvée par le créancier et du gain dont il a été privé, que ce qui est une suite immédiate et directe de l'inexécution de la convention. (Even in the case where the non-performance of the agreement is due to the debtor's intentional breach, damages may include, with respect to the loss suffered by the creditor and the profit which he has been deprived of, only what is an immediate and direct consequence of the non-performance of the agreement. $)^{26}$

Baron Parke noted, at the time, that the English translation of the French rules referred to was that "[t]he debtor is only liable for the damages foreseen or which might have been foreseen, at the time of the execution of the contract, when it is not owing to his fraud that the agreement has been violated." 27 Hence, the "foreseeability" rule of Hadley v. Baxendale was influenced greatly by, if not outright adopted from, the French civil law of contracts.

During the argument of the case, Baxendale's lawyer, Sir James Willes, made references generally to the fact that both American and English cases had generally refused recovery of profits except in cases of "special contracts," and also referred generally to the fact that parties should not be liable for damages "beyond all human foresight."28 From the written report of the case, it appears that Hadley's counsel first injected the citation to French authority, though apparently in order to argue that its precepts were satisfied-i.e., that the lost profit damages in question were indeed foreseeable to Baxendale's shipping company. ${ }^{29}$ However, it is likely that Willes contributed to the discussion of the civil law concepts during the course of the argument. Richard Danzig has argued that Willes' involvement in the case was pivotal to the outcome. ${ }^{30}$ This was due in part to his accomplished ability and widespread fame, but it was also due to his knowledge of foreign law. ${ }^{31}$ As Danzig states, Willes' "commercial interests combined with his academic orientation and his cosmopolitan outlook caused Willes

26. Legifrance: Le Service Public de la Diffusion du Droit, Civil Code, Art. 1149, 1150, 1151, available at http://www.legifrance.gouv.fr/html/codes/traduits/liste.html (last visited Feb. 9, 2005) (on file with the Texas Wesleyan Law Review) [hereinafter Legifrance, Civil Code] (containing both French text and English translations of the French Civil Code).

27. Hadley, 156 Eng. Rep. at 147-48. Parke referred to "Sedgwick," a noted treatise of the day. Id. at 147. See generally Theodore Sedgwick, A Treatise on THE Measure of Damages (Arthur G. Sedgwick \& Joseph H. Beale eds., Baker, Voorhis \& Co. 9th ed. 1920) (1847).

28. See Hadley, 156 Eng. Rep. at 149-50.

29. See id. at 147-48.

30. Danzig, supra note 3, at $257-58$ ("[T]he fact that Willes was a principal actor in the case was of no small significance in effecting the spread of the rule.").

31. Id. at 258 . 
to be thoroughly familiar with the French Civil Code's provision on damages ...."32

Further, during the argument Baron Parke also mentioned Sedgwick's American treatise when invoking the French civil code rules on damage recovery. ${ }^{33}$ Indeed, the Sedwick treatise did advocate limitations on contract recovery much like that announced by the Hadley decision. ${ }^{34}$ Moreover, unsurprisingly, the noted French jurist Robert Joseph Pothier also explicated the French rules of limited contract liability. ${ }^{35}$ In his treatise, Pothier set forth the following as the rule in France:

"When the debtor cannot be charged with any fraud, and is merely in fault for not performing his obligation, ... the debtor is only liable for the damages and interest which might have been contemplated at the time of the contract; for to such alone the debtor can be considered as having intended to submit."36

Lawyers in both England and America would have been well aware of Pothier's discourse on the law of contracts and damages, as his texts were some of the first English-language treatises available. ${ }^{37}$ Moreover, Pothier's damages formulation was contained, in some variation, in the treatises of Chapman, Kent, and Sedgwick. ${ }^{38}$ Hence, it is seen that, at the time that Pothier's treatise was published in England in 1806 , it was readily studied and adapted because it presented "'general principles of contract law which modern English lawyers were particularly looking for." 39 Simply put, the English common law had

32. Id.

33. Hadley, 156 Eng. Rep. at 147-48.

34. See Danzig, supra note 3, at 257 (citing A.W.B. Simpson, Innovation in Contract Law (unpublished manuscript available from Prof. Simpson, Keynes College, The University of Kent, Canterbury, England)). The Sedgwick treatise stated:

"[T]he damages which a party can recover on the breach of a contract, are those which are incidental and caused by the breach, and may reasonably be supposed to have entered into the contemplation of the parties at the time of the contract"; and this is perhaps the clearest and most definite line that can be drawn in the matter.

Danzig, supra note 3 , at 257 n.35 (quoting Theodore Sedgwick, A Treatise on the Measure of Damages 67 (2d ed. 1852).

35. See Danzig, supra note 3, at 257 (citing Robert Joseph Pothier, A Treatise on the Law of Obligations, or Contracts, pt. I, ch. II, art. III, $\S \S 16$ ff. (William David Evans trans., 1806)).

36. Faust, supra note 2, at 42 (quoting Pothier, supra note 35 , at part 1, ch. 2, art. 3, s. 160).

37. Id. at 43 (citing S.F.C. Milsom, A Pageant in Modern Dress, 84 YALE L.J. 1585, 1589 (1975) (book review)). A translation was published in America in 1802, while a British translation was published in 1806. See id. at 65 n.16.

38. Id. at 43 (citing Daniel Chapman, An Essay on the Law of Contracts, For the Payment of Specific Articles 121-23 (1822); Kent's Commentaries, Vol. 2, p. *480, note (4th ed. 1840); Theodore Sedgwick, A Treatise on the MeASURE OF DAMAGEs 64-67 (1847)).

39. Id. at 61 (citing P.S. Atiyah, The Rise and Fall of Freedom of Contract 399 (1979)). 
undeveloped areas in it, which the civil law was readily able to provide. It has thus been argued elsewhere that Hadley was merely illustrative of a larger tendency in 19th century English law of the adaptation of civil law treatise doctrines into the holdings of the English cases. ${ }^{40}$

To pick up on the previous discussion of the pedigree of Article 74 of the CISG, ${ }^{41}$ it is obviously unlikely that French scholars would ever attribute its heritage to the English common law and Hadley. ${ }^{42}$ The French civil code has long had provisions regarding foreseeability limitations on recovery of contracts damages, as noted previously. ${ }^{43}$ Italy's civil code also has similar limitations. ${ }^{44}$ Even the Louisiana Civil Code, based largely on the Napoleonic Code in France, contains a similar provision. ${ }^{45}$ Hence, for scholars and practitioners in civil law countries, CISG Article 74's heritage is easily seen in their civil codes, and recourse to Hadley is entirely unnecessary.

\section{Blanchard v. Ely: Predecessor to Hadley Which Overtly Acknowledged the Civil Law}

Interestingly, Hadley was not the first Anglo-American common law court to craft or apply a foreseeability limitation on the recovery of damages. That distinction would appear to belong to the $1839 \mathrm{New}$ York case of Blanchard v. Ely. ${ }^{46}$ In Blanchard, the defendant had contracted with the plaintiff for the construction of a steamship. ${ }^{47}$ There were several manufacturing and materials defects with the ship, causing defendant numerous problems on attempted trips on the Susquehanna River, including delays and broken shafts. ${ }^{48}$ The delays caused the defendant to lose a certain amount of profits for every voyage that was delayed or canceled, for recovery of which it sought along with the costs necessary to repair the ship. ${ }^{49}$ The original contract price for the boat was $\$ 12,500 .^{50}$ Defendant had paid $\$ 7,975.34$ towards the price previously, and the plaintiff initially sued for the balance of the $\$ 12,500$, plus interest-defendant counterclaimed for

40. See Danzig, supra note 3, at 257 (citing Simpson, supra note 34 , at 48 ).

41. See supra notes 22-24 and accompanying text.

42. See Ferrari, supra note 23 , at 1263 .

43. See supra notes $25-27$ and accompanying text.

44. Ferrari, supra note 23, at 1263 (citing article 1225 of the Italian Civil Code, which provides: "[U]nless the non-performance or the delay depends on the debtor's fraud, the compensation is limited to the damages which could be foreseen at the time when the obligation came into existence." ").

45. See LA. Civ. Code AnN. art. 1996 (West 1987) ("An obligor in good faith is liable only for the damages that were foreseeable at the time the contract was made.").

46. 21 Wend. 342 (N.Y. Sup. Ct. 1839).

47. Id. at 342 .

48. Id. at $342-43$.

49. Id.

50. Id. at 342 . 
the deduction of his damages, both repair costs and lost profits occasioned by the delay in the boat being completed. ${ }^{51}$ At the original trial, the jury granted judgment for plaintiff in the amount of $\$ 5,240.31$, an amount which appeared to give plaintiff the full contract balance remaining on the boat, plus interest, and without any deduction for any of defendant's claimed damages. ${ }^{52}$ Moreover, the trial judge had instructed the jury that they could account for cost to repair defects in the boat, but they could not account for any lost profits. ${ }^{53}$ Defendant requested a new trial. ${ }^{54}$

In considering the various points of error assigned, the Supreme Court of Judicature of New York analyzed whether the trial court had limited the jury too acutely in its damage formulation prohibiting the inclusion of lost profits. ${ }^{55}$ The court noted that there appeared to be no common law authority for this damage-limiting proposition ${ }^{56}$-indeed, Hadley was yet fifteen years away from being decided. The court reviewed a handful of recent decisions on damages, and surmised "that on the subject in question, our courts are more and more falling into the track of the civil law ...."57 The court identified the "civil law track" as being none other than a Pothier formulation: " "In general, the parties are deemed to have contemplated only the damages and interest which the creditor might suffer from the nonperformance of the obligation, in respect to the particular thing which is the object of it ...."'s8 Thus, the court held that profits should be excluded as unforeseen, unless fraud or willful conduct was involved, which was also part of the French law. ${ }^{59}$

Thus, it is seen that the Blanchard court had similar thoughts as the Hadley court about the foreseeability limitation on the recovery of damages for breach of contract. Both cited French civil lawBlanchard cited the Pothier treatise, whereas the Hadley reference was directly to the French civil code. However, both citations were of the same basic effect. The civil law was borrowed and adapted as the basis for a common law formulation of a limiting principle in the recovery of damages for breach of contract.

51. Id. at 343 .

52. Id. at 344 .

53. Id. at 343 .

54. Id. at 344 .

55. Id. at 345 .

56. Id.

57. Id. at 347 .

58. Id. at 347-48 (quoting 1 Evan's Poth. 91, Lond. ed. 1806).

59. Id. at 349. The court nevertheless granted a new trial, because the jury appeared to have awarded the defendant no recovery, even though the evidence clearly showed there were some costs involved in repairing certain defects in the boat. Id. at 349-50. However, the error assigned to the trial court's prohibiting recovery of profits was upheld. Id. at 350. 


\section{The Lineage of the Rule Limiting Contracts Damages on the Basis of Foreseeability}

The concept of limiting recovery for contracts damages which are foreseeable can be traced to Roman law. ${ }^{60}$ In a constitution enacted by Justinian in 531 A.D., damages were said to be "limited ad duplum." ${ }^{\text {"61 }}$ This principle stood virtually unopposed for a millennium, and in 1546, the noted French jurist Charles Dumoulin asserted that the reasoning of this Roman constitutional provision was that, under ordinary circumstances, the breaching party would only be able to actually foresee this type of injury, that is, the duplum. ${ }^{62}$ Accordingly, in his French texts Dumoulin adopted this Roman principle, and formulated the rule that damages arising from a contract breach were only recoverable if they were foreseeable. ${ }^{63}$ Ultimately, it was Dumoulin whom Pothier cited for his treatise's conclusion that the foreseeability limitation was firmly embedded in pre-Napoleonic Code French law. ${ }^{64}$

And Pothier's influence was nothing short of profound. As noted earlier, a New York court cited Pothier in a decision-Blanchard $v$. Ely - which advocated a foreseeability limitation to contract recovery some 15 years before Hadley was decided. ${ }^{65}$ Pothier's treatise was, therefore, largely responsible for spreading the idea of limiting con-

60. Ferrari, supra note 23, at 1264.

A vague attempt to limit the compensation of damages in contract law to foreseeable damages was made in Roman law, but these attempts were nullified by a constitution enacted in 531 A.D. by Justinian according to which damages were limited ad duplum. However, one can consider this constitution as the "starting point" of the "foreseeability" limit which can be found in many legal systems based on French law.

Id.

61. Id.

62. Id. (citing Auguste Dumas, Les origines romaines de l'article 1150 du Code civil, in 2 Etudes d'Histoire juridique offertes a Paul Frédéric Girard 110 (1913)). Dumoulin led a fascinating life. He was a descendant of a family which was related to Anne Boleyn, the mother of Elizabeth I of England. See A. Van Hove, Charles Dumoulin, in 5 The Catholic EncrClopedia (Robert Appleton Co. 1909), available at http://www.newadvent.org/cathen/05190c.htm (last visited Feb. 2, 2005) (on file with the Texas Wesleyan Law Review). In addition to being a renowned legal scholar, he virulently opposed Catholicism and the papacy during most of his life, though he was reconciled to the Church at his death. Id. Of his scholarly knowledge, he is reputed to have said: "'Ego qui nemini cedo nee a nemine doceri possum' (I yield to no one nor is anyone able to teach me)." Id.

63. Ferrari, supra note 23, at 1264.

64. Id. (citing Oeuvres De Pothier 181 (1821)). The statement made by Pothier which referenced Dumoulin was: "'le débiteur n'est tenu que des dommages et intéréts qu'on a pu prévoir, lors du contrat, que le créancier pourrait souffrir de l'inexécution de l'obligation; car le débiteur est censé ne s'être soumis qu'a ceux-ci."' ("The debtor is bound to pay only the damages and interests which one could foresee, when the contract was made, as being possibly suffered by the creditor in nonperforming the obligation, because the debtor is considered as having accepted only these." ") Id. at $1264 \&$ n.50 (quoting Oeuvres de Pothier 181 (1821)).

65. See supra notes $46-59$ and accompanying text. 
tract liability. ${ }^{66}$ This was the case in England, but even more so in the United States, "where 'in order to solve new legal problems one referred to English law, as well as to civil law." "67 Of Pothier's treatises, it has correctly been asserted that they "constituted, apart from the Louisiana Civil Code, the easiest way to access the legal tradition of the European continent." "68 Accordingly, it is unsurprising that, in addition to Blanchard v. Ely, several American cases cited Pothier's treatise in their conclusions, acknowledging it as the true source of the Hadley rule. ${ }^{69}$

For instance, in Jones v. George ${ }^{70}$ the Texas Supreme Court traced the lineage of the foreseeability rule and its origins. Acknowledging the authoritative pronouncement of Hadley, it nevertheless stated that the rule was "largely drawn from the civil law."71 Moreover, the Texas court noted that most jurisdictions in the United States followed the rule, including the Louisiana Supreme Court. ${ }^{72}$ The Louisiana rule, in turn, the court noted, was based on the Louisiana Code-and the Louisiana Code was based largely on the Napoleonic Code, which was based on Pothier, which was stated to be based directly on Roman law. ${ }^{73}$ Similarly, in Manss-Owens Co. v. H.S. Owens \& Son,$^{74}$ the court stated in regard to the rule in Hadley: "[although it] is sometimes spoken of as having originated in that case, it is in reality an embodiment of civil-law principles, and is substantially a paraphrasing of the rule on the subject as it had been stated at an earlier date in the Code Napoleon, by Pothier, and by Chancellor Kent."75 Based on this evidence, and on the record in Hadley itself, it is little wonder that Pothier-the French civil law jurist-is regarded as the architect of the modern rule limiting contract recovery to foreseeable damages. ${ }^{76}$

66. See Ferrari, supra note 23, at 1265.

67. Id. (quoting Detlef König, Voraussehbarkeit des Schadens als Grenze vertraglicher Haftung, in Das HaAger Einheitliche Kaufgesetz und das Deutsche Schuldrecht. Kolloquium Zum 65. Geburtstag von Ernst v. Caemmerer 80 (Hans G. Leser \& Wolfgang Frhr. Marschall von Bieberstein eds., 1973)).

68. Id. (quoting König, supra note 67 , at 80 ).

69. See, e.g., Griffin v. Colver, 16 N.Y. 489 (1858); Masterton \& Smith v. Mayor of Brooklyn, 7 Hill 61 (N.Y. Sup. Ct. 1845); Jones v. George, 61 Tex. 345 (1884); Sinclair Ref. Co. v. Hamilton \& Dotson, 178 S.E. 777 (Va. 1935); Manss-Owens Co. v. H. S. Owens \& Son, 105 S.E. 543 (Va. 1921).

70. 61 Tex. 345.

71. Id. at 354 .

72. $I d$. at 355 .

73. Id. at 355-56 ("The rule in Louisiana seems to be established by the code of that state (1 Sedgwick, 103; Williams v. Barton, 13 La., 410); and it and its modifications are taken from the Code Napoleon, 1149, 1150, which in turn are taken from Pothier on Obligations, Nos. 159, 160, who asserts that the rule is as old as the Roman law.").

74. 105 S.E. 543.

75. Id. at 549 .

76. See Ferrari, supra note 23, at 1265 ("Pothier has been expressly referred to as the inventor of the rule which limits contractual liability to the foreseeable damage."). 


\section{The Concept of Legal Borrowing Generally}

\section{A. The History of Common Law Borrowing from the Civil Law}

If one believes that Hadley's borrowing from the civil law was a rare occurrence, such a conclusion would most assuredly be inaccurate. At least from the days of the Norman Conquest, and especially in the 19th century, the common law and the civil law have continually imported and exported legal ideas and doctrines to and from each other. ${ }^{77}$ Thus, Hadley's importation of a civil law rule into the English common law system is actually, historically speaking, not a startling phenomenon at all. Such transplanting of foreign rules into domestic legal systems has been occurring throughout most of Western history-certainly since the Roman republic and empire. ${ }^{78}$ Not only that, but the transplantation of foreign rules into legal domestic systems is actually the most frequent basis for legal development, as opposed to legal invention by the members of the bar and the academic community. ${ }^{79}$ For instance, the most basic of commercial instruments-the sales contract-is remarkably unchanged from the arrangement which pertained in the Roman Empire. ${ }^{80}$

Lawyers, by their nature, have always sought authority for their positions. ${ }^{81}$ When the authority has not been present in their domestic system, they tend to seek persuasive authority elsewhere, and hence the context is then ripe for borrowing foreign legal rules. ${ }^{82}$ Though in theory the lawyer should seek to find the superior doctrine from among the plethora of foreign legal systems available, in actual practice certain bodies of law tend to be resorted to time and againnamely, "Roman law after the rediscovery of the Corpus Juris Civilis, [and] the French Code Civil after its promulgation." ${ }^{83}$ These are chosen because they are written down, they are widely accessible, and also because they have a staggering amount of historical pedigree and credibility. ${ }^{84}$ Plus, of such obvious significance as to scarcely need assertion, the Roman civil law came before the common law-hence the propensity of the latter to borrow from the former.

The early uses of Roman law in England were occasionally criticized. Frederic W. Maitland observed: "It shows us how men were helplessly looking about for some general principles of Jurisprudence

77. See Gunther A. Weiss, The Enchantment of Codification in the Common-Law World, 25 YALE J. INT'L L. 435, 438 (2000).

78. See Alan Watson, Legal Transplants: An Approach to Comparative Law 95 (2d ed. 1993) [hereinafter Watson, Legal Transplants].

79. Id. ("[T]ransplanting is, in fact, the most fertile source of development. Most changes in most systems are the result of borrowing.").

80. Id.

81. Alan Watson, The Evolution of Western Private Law 263 (expanded ed. 2001) [hereinafter WAtSON, The Evolution].

82. Id.

83. Id. (emphasis added).

84. Id. 
which would deliver them from their practical and intellectual difficulties." ${ }^{85}$ Nevertheless, during the pivotal period of development of the common law during the 16 th and 17 th centuries, there was a clear increase in the borrowings and reasonings from Roman civil law. ${ }^{86}$ This was most common when, as was the case for many areas of English common law at the time, there were gaps in it which needed to be filled in with newly created doctrine. ${ }^{87}$ Here, Roman law often, if surreptitiously, helped to fill the void. ${ }^{88}$ As Henry Sumner Maine observed in his venerable work Ancient Law:

The [English common law] judges of the thirteenth century may have really had at their command a mine of law unrevealed to the bar and to the lay-public, for there is some reason for suspecting that in secret they borrowed freely, though not always wisely, from current compendia of the Roman and Canon laws. ${ }^{89}$

Of course, the more time passed and English precedents were decided, the fewer gaps there were and the less resort was had to Roman or civil law. ${ }^{90}$

\section{B. The Debate About the Correlation Between Societies and the Development of the Rule of Law}

The historical transplantation of foreign legal rules has not been as difficult, nor as much the subject of any particular controversy, as one might cursorily expect. Though there is often resistance from lawyers and government officials to the infiltration of foreign legal doctrines, commercial actors by and large are relatively unconcerned with matters of national pride and origin in their rules - they simply want to know that such rules do exist in the case of a dispute between them in their affairs, and they want to know what those rules are for business planning purposes. ${ }^{91}$ The content of the rule is less important than the

85. Frederick Pollock \& Frederick William Mattland, The History of English LaW Before the Time of Edward I 102 (Lawbook Exchange 2d ed. 1996) (1898).

86. WATSON, The Evolution, supra note 81, at 241.

87. Id.

88. Id.

89. Henry Sumner Maine, Ancient Law 32-33 (Transaction Publishers 2002) (1866).

90. WAtson, The Evolution, supra note 81, at 243.

The use of precedent also militates against the infiltration of Roman law.

First, there are fewer gaps to be filled. Second, gaps can be filled by analogy with previous cases. Third, where judges are given the high social status of lawmakers-even if they talk as if their role was that of law finders-they will bolster their own position and prestige by relying on the authority of other judges rather than looking elsewhere for authority.

Id.; see also MAINE, supra note 89, at 33 (stating that resort to the Roman law "storehouse was closed as soon as the points decided at Westminster Hall became numerous enough to supply a basis for a substantive system of jurisprudence ....").

91. See Watson, Legal Transplants, supra note 78, at 95-96. 
fact that there is one. ${ }^{92}$ This, then, undermines the widely-held belief that legal rules and doctrines are quintessentially a function of the society in which they arise-this may be a factor, but it is clear, given the historical frequency of legal borrowings, that timely societal interaction is not the sine qua non of the development of legal rules and precepts for governing the affairs of the people of that society. ${ }^{93}$

Richard Danzig, in a widely-cited article, postulated that the Hadley rule, decided as it was without common law precedent in the middle of the industrial revolution in 1854 , must be seen as evidence of a "judicial invention" by the common law to rapidly accommodate the commercial needs of the day. ${ }^{94}$ Danzig criticized a view espoused by a contemporary at the time, A.W.B. Simpson, "that innovation in the law in the nineteenth century was largely prompted by the quiet absorption of the observations of treatise writers, particularly treatise writers influenced by the civil law, into the decisions of English common law judges." 95 This view, though commendable to Danzig, was insufficient in his estimation because it overlooked the contribution of Baxendale's lawyer, Sir James Shaw Willes, and also because it minimized the significance of the domestic exigencies which called for a new rule regarding damages in England at that point in history. ${ }^{96}$

In point of fact, there are scholars who disagree with Danzig's criticisms in this regard. Alan Watson, for one, espouses a theory that law and society share no innate affiliation with one another-they are rather two completely separate things altogether. ${ }^{97}$ That is, Watson asserts that "law develops by transplanting, not because some such rule was the inevitable consequence of the social structure and would have emerged even without a model to copy, but because the foreign rule was known to those with control over lawmaking, and they observed the apparent merits that could be derived from it."98 In Watson's view, there are nine factors which indicate whether the time is suitable for the transplanting of a foreign rule into a domestic legal system: "pressure force, opposition force, transplant bias, discretion factor, generality factor, societal inertia, felt-needs, source of law, and law-shaping lawyers." 99 The rationale for transplanting is obvious-

92. See id. at 96.

93. See id. at 96-97.

94. See generally Danzig, supra note 3.

95. Id. at 257.

96. See id. at 257-59.

97. Loukas A. Mistelis, Regulatory Aspects: Globalization, Harmonization, Legal Transplants, and Law Reform-Some Fundamental Observations, 34 INT'L LAw. 1055, 1066 \& n.72 (2000) (citing Alan Watson, Comparative Law and Legal Change, 37 CAmbridge L.J. 313, 313-14, 321 (1978) ("There is no exact, fixed, close, complete, or necessary correlation between social, economic, or political circumstances and a system of rules of private law.")).

98. Id. at 1066 (citing Watson, supra note 97 , at 315 ).

99. Id. at 1066 n.75 (citing Watson, supra note 97, at 322). 
"there is no need for legislators to struggle to reinvent the wheel when others have dealt with the same issues." 100

The situation in Hadley could be argued to follow along Watson's and Simpson's model, rather than Danzig's. The French rule stated in Pothier, after all, existed long before the industrial revolution had swept across Europe. Indeed, the rule by most accounts apparently harkens back to the days of the Roman Empire. And yet, no state of industrialized advancement existed at that time, to the extent that it did in 19th century Europe and America. What, then, accounts for the fact that the contemplated rule existed in Rome and pre-revolutionary France, but not England or America until later in the 19th century? It would appear that, the greater core of civilization in continental Europe being hundreds, if not thousands, of years older than England and certainly the United States, the continental jurists had simply ascertained the need for such a rule at an earlier date than had the Anglo-American civilizations. It is quite arguable that, rather than the adoption of the rule by Hadley in 1854 being the product of the industrial era of the day, that was simply a fortuitous circumstance-a historical accident. That the rule existed in pre-revolutionary France and Rome suggests that there is nothing inherent in the rule which suggests that the need for it has anything exclusively to do with an industrialized society. Rather, it is an inherently logical resolution of the problem of uncontemplated damages scenarios befalling the contracting parties. When finally the English and American courts grappled with and focused on the problem, they found their continental brethren had already addressed the issue, and there was simply no need for them to attempt to craft an entirely different solution when the civilian one was already so elegantly articulated.

This is not, however, to suggest that Danzig's hypothesis that the Hadley judges were, to some degree, attempting to address a felt societal and commercial need of the day is without merit. Indeed, it would appear that both theories were at work in the Hadley decision-a need for a common law rule where there was none previously, and a ready solution adaptable from the civil law. Thus, as stated by Ferrari:

[I]t has been argued that the [Hadley] rule at issue can be analyzed as a judicial invention in an age of industrial invention, i.e., as an invention linked to a society characterized by the industrial revolution. However, as it results from the text of the decision rendered by the Court of Exchequer, this view is not tenable: the Hadley rule does not constitute a judicial invention in an age of industrial invention. It constitutes rather the transplantation of a foreign rule, made necessary by the age of industrial invention. This is the con-

100. Id. at 1067 (citing Thomas W. Waelde \& James Gunderson, Legislative Reform in Transition Economies; Western Transplants-A Short Cut to Social Market Status?, 43 INT'L \& CoMp. L. Q. 347 (1994)). 
clusion one must draw from reading the text of Hadley v. Baxendale. It is apparent that the judges of Hadley were aware . . of the French rule since they stated that "the sensible rule appears to be that which has been laid down in France, and which is declared in their code-Code Civil 1149, 1150, 1151."101

Hence, there is room for some of all of the views mentioned. Hadley was based, at least in part, on the stimulus provided by the needs of the newly emerging industrial era. And yet it is also quite clearly seen in the historical sense as a legal transplant, rather than an "invention," with the selected rule coming directly from the French civil law. The rule, having existed for centuries prior to any industrialization of society in the modern sense, would seemingly defy any attempt to assert a theory of inevitable correlation with English 19th century industrialization.

\section{Examples of Other Common LaW Borrowing FROM THE Civil LAW}

The English, and later American courts, were only beginning to develop and flesh out the precepts of the common law in the 17 th and 18 th centuries, and thus were starting with the proverbial clean slate. It is, thus, hardly surprising that, when the common law jurists of the day were presented with a situation in which there was no settled principle, they often looked to the civil law for a ready-made solution. ${ }^{102}$ The civil law, and especially its Roman origins, provided a tremendously respected source for potential importation of doctrine. Though neither England nor its former colonies ever received the Roman law formally as did many of the Continental European nations, it was nevertheless quite influential:

"The Roman law forms no rule, binding in itself, upon the subjects of this realm, but in deciding a case upon principle, where no direct authority can be cited from our books, it affords no small evidence of the soundness of the conclusion at which we have arrived, if it proves to be supported by that law, the fruit of the researches of the most learned men, the collective wisdom of ages, and the groundwork of the municipal law of most of the countries of Europe."103

101. Ferrari, supra note 23, at 1267 (quoting Hadley v. Baxendale, 156 Eng. Rep. 145, 147 (Ex. 1854), and citing Theodore SedGwick, Treatise on the Measure of Damages (1847), and Danzig, supra note 3, at 250).

102. See Danzig, supra note 3, at 258-59. "A foreign model . . sharpens discussion and provides a ready made plan . . . ." Id. (quoting Lawrence M. Friedman \& Jack Ladinsky, Social Change and the Law of Industrial Accidents, 67 Colum. L. Rev. 50, 78 (1967)).

103. Thibaudeau Rinfret, The Relations Between Civil Law and Common Law, in The Code Napoleon and the Common-Law World 385 (Bernard Schwartz ed., The Lawbook Exch., Ltd. 1998) (1956) (quoting Acton v. Blundell, 12 M. \& W. 324, 353 (1848)). 
A similar view of the persuasiveness of Roman law was stated by Brown in The Common Law of England: "Our courts will listen to arguments drawn from the Institutes and Pandects of Justinian, and will rejoice if their conclusions are shown to be in conformity with that law." "104 Anglo-American courts derived, therefore, a large degree of credibility and legitimacy from determining that their doctrinal pronouncements were in accord with the ancient Roman law. ${ }^{105}$ Hence, if Hadley $v$. Baxendale is one of the more prominent (though largely unheralded) examples of a common law borrowing from the civil law, it is hardly the only one. A few examples, set forth below, should suffice to make the point.

\section{A. The Privilege Against Self-Incrimination}

The privilege against self-incrimination had its beginnings in 16th and 17th century England. ${ }^{106}$ This right is widely thought to have been fashioned from a dispute between the prerogative courts and religious groups about the appropriateness of the ex officio oath. ${ }^{107}$ The common law courts issued writs of prohibition and habeas corpus, in order to prevent the ex officio oath from being administered by the prerogative courts. ${ }^{108}$ Those who sided with the common law courts' aversion to the ex officio oath's propensity for imposing self-incrimination contended that this practice was violative of certain basic rights. ${ }^{109}$ Levy states that the historical episode may be characterized

104. Id. (quoting Brom, The Common Law of England 20 (9th ed. 1896)).

105. See Arthur Taylor von Mehren \& James Russell Gordley, The Civil Law System: An Introduction to The Comparative Study of Law 13 (2d ed. 1977). One author wrote:

"Civil law did not become a constituent element of English common law acknowledged and enforced by the courts, but it exercised a potent influence on the formation of legal doctrines during the critical twelfth and thirteenth centuries, when the foundations of common law were laid .... The only real test of its character and extent is afforded by the development of juridical ideas, and in this respect the initial influence of Roman teaching on English doctrines will be found to be considerable. On many subjects the judges and legal writers of England were, as it were, prompted by their Roman predecessors, and this intercourse of ideas is nowhere as conspicuous as in the frequent cases when English writers did not simply copy their Roman models, but borrowed suggestions from them in order to develop them in their own way."

Id. at 13 n. 53 (quoting P. Vinogradoff, Roman Law in Medieval Europe 97 , 117-18 (2d ed. 1929)).

106. See R.H. Helmholz, Continental Law and Common Law: Historical Strangers or Companions?, 1990 DUKE L.J. 1207, 1216-17 (1990).

107. Id. (citing L. Levy, Origins of the Fifth Amendment (2d ed. 1986), N. Tyacke, Anti-Calvinists: The Rise of English Arminianism C. 1590-1640, at 67-71, 85-86 (1987), and Maguire, Attack of the Common Lawyers on the Oath exofficio as Administered in the Ecclesiastical Courts in England, in EsSAYS IN HISTORY and Political Theory in Honor of Charles Howard McIlwain 199 (1936)).

108. Id. at 1217.

109. Id. 
as an English chafing against a foreign legal system. ${ }^{110}$ However, this is an oversimplification. In fact, the English advocates were not merely arguing that the oath was in contravention of English freedom-they were contending that it was internally violative of the prerogative courts' own rules of procedure. ${ }^{111}$ These rules, in turn, stemmed from Continental sources of law, of civilian and Roman origin. For instance, the privilege against self-incrimination is actually found in glossated manuscripts of Gregorian Decretals. ${ }^{112}$ It was also found in civil law treatises on procedure of that era. ${ }^{113}$ Thus, when jurists such as Sir Edward Coke promoted the right against self-incrimination by citing maxims such as "nemo tenetur prodere seipsum," the authority was not English-it was Roman/Continental, i.e., civilian. ${ }^{114}$

\section{B. Mitior Sensus Doctrine in Law of Defamation}

Early in English common law history, the law of defamation began to be developed. One of the doctrines which arose quickly in regard to this area of law was the mitior sensus doctrine-this doctrine stated that in defamation actions, where possible a court would construe the allegedly defamatory communication as not being defamatory. ${ }^{115}$ To cite a single example of attempted use of this doctrine, when a person stated about a lawyer that "he hath as much law as a jackanapes," the mitior sensus argument would be that by such statement was only meant that the lawyer was as knowledgeable as a jackanapes, and then some; i.e., the jackanapes statement was merely a threshold assessment. ${ }^{116}$ From whence did this doctrine originate? It, too, originated from the continental civil law. The rule appears in fairly identical

110. Id.

111. Id.

112. Id. at 1218 (citing glossa ordinaria ad X 2.20 .37 (Cum causam) s.v. de causis).

113. Id. (citing SYNTAGMA COMMUNIUM OPINIONUM (Lyons 1608), Lib VII, tit. 19, no. 21 ("Positionibus criminosis aut captiosis per quas delictum aut periurium detegi posset, nemo tenetur respondere") ("No one is bound to answer incriminating or captious positiones by which a delict or perjury might come to light"), and JOACHIM Mynsinger (d. 1588), Singularium OBSERVATIONUM IUDICII IMPERIALIS CAMERAE (1595), Cent. VI, Obs. 92 ("quia nemo se ipsum prodere tenetur") ("because no one is bound to betray himself")).

114. Id. (citing Rochester v. Mascall (C.P. 1608), British Library, London, Stowe MS. 424, fol. 160v ("Quod per legem terrae nemo tenetur in causis criminalibus prodere seipsum.") ("That by the law of the land no one is bound to betray himself in criminal causes.")).

115. Id. at 1218-19 (citing W. Keeton, D. Dobbs, R. Keeton \& D. Owen, ProsSER AND KeETON ON TORTS $\S 111$, at 781 (5th ed. 1984), 2 F. HARPER \& F. James, The Law of Torts $\$ 5.29$, at 245-47 (O. Gray 2d. ed., 1986), L. Eldredge, The LAW OF Defamation $\$ 24$, at 161 (1978), and J. BAKER, INTRODUCTION TO ENGLish Legal History 368-70 (2d. ed. 1979)).

116. Id. at 1219 (citing Palmer v. Boyer, Goulds. 126, 75 Eng. Rep. 1040, 1041 (K.B. 1601)). Helmholz notes, in his article, that this apparently far-reaching attempt at application of the mitior sensus doctrine in this context was rejected by the court. Id. at 1219 n.47. 
form in the Roman Law Digest. ${ }^{117}$ Again, it also appears in many of the civil law treatises of the day. ${ }^{118}$ The civil law heritage of the rule is thus unmistakable.

\section{Law of Conflicts}

Justice Joseph Story was instrumental in developing the American theories of conflicts of law analysis. ${ }^{119}$ Cases in this area at the time of Story's judicial reign were scarce, and so he looked to the civil law for assistance in developing a conflict jurisprudence. ${ }^{120}$ As he stated, Story endeavored to "use the works of the civilians, to illustrate, confirm, and expand the doctrines of the common law." 121 Story not only did this in his treatises and scholarly work, but also in his court opinions as well. For example, in Van Reimsdyk v. Kane, ${ }^{122}$ Story cited the 16th century Dutch civil law jurist Ulrich Huber for the following proposition:

[T] he law of the place, where a contract is made, is to govern, as to the nature, validity, and construction of such contract; and that being valid in such state, it is to be considered as equally valid, and to be enforced everywhere, with the exception of cases in which the contract is immoral or unjust, or in which the enforcing it in a state will be injurious to the rights, the interest, or the convenience of such state or its citizens. ${ }^{123}$

Moreover, Story was not the only jurist who was making use of civil law authority in adjudicating conflicts cases during this general period. For instance, in the 1803 case of Nash v. Tupper, ${ }^{124}$ there was a difference in whether suit on a debt was barred, based on whether New York law or Connecticut law applied, respectively. ${ }^{125}$ The court cited the French scholar Emerigon for the proposition that domestic courts were not destroying their own sovereignty by applying the laws of the

117. $I d$. at 1220 (citing Dig. 50.17.56).

118. Id. (citing Johannes Gutierrez (d. 1618), Praxis CRiminalis Civilis et CaNONICA, Quaest. 65, no. 2 (Lyons 1661) ("[I]nterpretatio sit facienda in meliorem partem, est regula iuris generalis."), JoHANNES SCHNEIDEWEIN (d. 1569), IN QUATUOR INSTITUTIONUM IMPERIALIUM JUSTINIANI LIBROS COMMENTARII, Lib. IV, tit. 4, no. 11 (1592) ("Quod quando verbum aliquod profertur, quod est indifferens et potest sonare injuriam vel non, tunc debet in mitiorem partem accipi."), and JACOBUS Menochius (d. 1607), De Praesumptionibus, coniecturis, signis, et indicis, Lib. V, Pr. 2, nos. 6-7 (Venice 1590) ("[Q]uando actus referri potest ad bonum et ad malum, in dubio refertur ad bonum, . . . in dubio, verba ita debere intelligi ne sonent in delictum.")).

119. See id. at 1222.

120. See id.

121. Id. (quoting J. Story, Commentaries on the Conflict of Laws 26 (3d ed. 1846)).

122. 28 F. Cas. 1062 (C.C.D.R.I. 1812) (No. 16,871).

123. Id. at 1063; see also Helmholz, supra note 106 , at 1222-23.

124. 1 Cai. R. 402 (N.Y. Sup. Ct. 1803).

125. Id. 
jurisdiction in which the contract was formed. ${ }^{126}$ There are many other examples of American courts citing Continental scholars for civilian precepts in conflicts cases. ${ }^{127}$ Thus, our American jurisprudence on conflicts of laws owes much to civilian sources and inspiration.

\section{Mistake Doctrine in Contracts Cases}

In the law of contracts, there is a principle which states that if the two parties make a mutual mistake regarding the subject matter of the contract, the contract is voidable, and thus, may be unenforceable. ${ }^{128}$ It turns out that this is a civil law concept which was imported into the common law of contracts. This has been widely recognized. For instance, in Iowa Loan \& Trust Co. v. Schnose, ${ }^{129}$ the South Dakota Supreme Court cited the general statement of the rule regarding mutual mistake, and then remarked: "Such was the civil law .... The same rule has been adopted as a part of the common law, and is based upon the idea that in such cases no contract has been consummated; that the minds of the parties have never met in respect to the real subject-matter of the contracts ...."130 The 17th century French scholar Jean Domat was cited for the civilian origins of the mistake rule. ${ }^{131}$ Indeed, Domat's treatise was influential, and this concept was eventually incorporated into the Napoleonic Code. ${ }^{132}$ Accordingly, the mistake doctrine in contract law is another example of the common law importation of civil law precepts.

\section{E. Rules of Equity}

In early English history, there developed a system of common law that was quite rigid, and it was structured into various specific writs of relief. ${ }^{133}$ Generally, only money damages were recoverable. ${ }^{134}$ Eventually, litigants who desired other types of relief sought it from the

126. Id. at 413-15.

127. See Helmholz, supra note 106, at 1223 n.66 (citing Robinson v. Campbell, 16 U.S. (3 Wheat.) 212, 219 (1818), Union Bank of Georgetown v. Smith, 24 F. Cas. 566, 573 (C.C.D.C. 1830) (No. 14,362), and Desesbats v. Berquier, 1 Binn. 336, 347 (Pa. 1808)).

128. See Restatement (Second) of Contracts $§ 152$ (1993).

129. 103 N.W. 22 (S.D. 1905).

130. Id. at 24 (quoting Bedell v. Wilder, 26 A. 589 (Vt. 1893)).

131. Id. (citing Domat's Civil Law, pt. 1 , bk. 1, tit. 18, \& 1, art. 7).

132. The English translation of Article 1109 of the French Civil Code is: "There is no valid consent, where the consent was given only by error, or where it was extorted by duress or abused by deception." See Legifrance, Civil Code, supra note 26, available at $\mathrm{http}: / / \mathrm{www}$. legifrance.gouv.fr/html/codes_traduits/code_civil_textA.htm\#Section $\% 20111 \% 20-\% 20$ Of $\% 20$ the $\% 200$ bject. Similarly, the English translation of Article 1110 is, in part, as follows: "Error is a ground for annulment of an agreement only where it rests on the very substance of the thing which is the object thereof." Id.

133. See John Henry Merryman, The Civil Law Tradition: An Introduction to the Legal Systems of Western Europe and Latin America 50-51 (2d ed. 1985).

134. See id. 
King, and then the King gradually delegated this adjudicatory responsibility to the office of the Chancellor, which evolved into the courts of chancery. ${ }^{135}$ The procedures, and the substantive rules, of the courts of equity were imported largely from the Continental canon law, and thus, were essentially of a Roman pedigree. ${ }^{136}$ Indeed, the chancery's "pervading spirit of equity and good conscience may also be credited to the churchly influence of the canon law."137 This spirit is seen in the various procedural remedies and rules which the courts of equity came to apply. For instance, the trust was an equitable doctrine in origin. ${ }^{138}$ It constitutes the creation of trustee-fiduciary obligations that are of the highest, most demanding recognized in the law. ${ }^{139}$ Moreover, the remedy of unjust enrichment was influenced by ecclesiastical concepts which were inherent in the Roman canon law of the church. ${ }^{140}$ Thus, our system of equitable remedies owes much to the Continental Roman law, which is bound up in the civilian tradition.

\section{F. Rules of Civil Procedure}

One of the primary characteristics of the civil law is, at least in its modern form, codification. ${ }^{141}$ David Dudley Field was a New York lawyer in the 19th century, who was a proponent of codifying both substantive and procedural law in a civilian fashion. ${ }^{142}$ Field sought to remedy judicial sluggishness, and the unduly complex characteristics of New York law, which he believed was indicative of the law in all of the United States. ${ }^{143}$ Field set forth his vision for codification as follows:

The records of the common law are in the reports of the decisions of the tribunals; the records of the statute law are in the volumes of legislative acts. To make a code of the known law is therefore but to make a complete, analytical, and authoritative compilation from these records .... [A] complete digest of our existing law, common and statute, dissected and analyzed, avoiding repetitions and rejecting contradictions, molded into distinct propositions, and arranged in scientific order, with proper amendments, and in this form

135. Id.

136. See Arthur T. Vanderbilt, The Reconciliation of the Civil Law and the Common Law, in The Code Napoleon and The Common-Law World 392-93 (Bernard Schwartz ed., 1998).

137. Id. at 393.

138. Id.

139. Id.

140. Id.

141. See Merryman, supra note 133, at 26-33.

142. See Weiss, supra note 77, at 503-04 (citing Charles Noble Gregory, Bentham and the Codifiers, 13 HARv. L. REv. 344, 356 (1900)).

143. Id. at 504. 
sanctioned by the Legislature, is the Code which the organic law commanded to be made for the people of this State. ${ }^{144}$

Field's efforts at codifying New York's substantive common law were largely a failure. ${ }^{145}$ However, he was quite successful in codifying New York's rules of civil procedure, and Field's theories remain the structural framework and inspiration for the American Federal Rules of Civil Procedure currently in force. ${ }^{146}$ Hence, our modern rules of civil procedure owe a great deal to civilian principles of codification.

\section{CONClusion}

Hadley v. Baxendale, though widely celebrated within the common law community as a great common law case, owes a great deal to the civil law, as it essentially adopted the applicable damages rules from the civil law and the French Civil Code, specifically. ${ }^{147}$ It turns out that this was not a rare or novel occurrence-rather, legal transplanting of doctrine from one legal system to another has been occurring for centuries. Specifically, it has been occurring in the form of common law borrowing from the older, developed civil law and Roman law for almost as long as the common law itself has been functioning, first in England, and later in most English-speaking parts of the world. The failure of England to formally receive the Corpus Juris Civilis did not prevent the common law courts from, nevertheless, being widely influenced by the Roman and civil law. Not only has the Hadley foreseeability rule been borrowed from the civil law, but so have numerous other doctrines, in whole or in part, including the privilege against self-incrimination, the mitior sensus doctrine in the law of defamation, much of the law of conflicts, the mistake doctrine in contracts law, the rules of equity, and the American Federal Rules of Civil Procedure.

This evidence seems to support the conclusion that the particular shape of legal doctrine as developed by the legal mechanisms of a society is not inevitably tied to the societal needs of the day. Rather, transplantation of rules from other societies, formed in other eras, can, and do, work reasonably well in spite of the heterogeneous nature of the respective societies in which they are implicated. The dawning of this realization can help foster future harmonization efforts between participants of divergent legal systems, given the fact that they share so much heritage in common.

144. Id. (quoting 1 David Dudley Field, Speeches, Arguments, and Miscellaneous Papers of David Dudley Field 326 (Abram P. Sprague ed., New York, Appleton \& Co. 1884)).

145. Id. at 506-08.

146. Id. at 505-06.

147. See supra notes $25-45$ and accompanying text. 